\title{
Social Factors Influencing Entrepreneurship A Study On With Special Reference To Theni District
}

\author{
Dr. S. Iruthaya Kalai Selvam ${ }^{1}$ Asha Banu ${ }^{2}$ \\ ${ }^{1}$ Assistant Professor of Zoology, PG and Research Centre of Zoology, Jayaraj Annapackiam College for Women \\ (Autonomous), Periyakulam, Theni district. Tamilnadu, India \\ 2Research Scholar, PG and Research Centre of Commerce, Jayaraj Annapackiam College for Women \\ (Autonomous), Periyakulam, Theni district. Tamilnadu, India
}

\section{Article Info}

Volume 7, Issue 4

Page Number: 314-322

\section{Publication Issue :}

July-August-2021

\section{Article History}

Accepted : 20 July 2021

Published : 25 July 2021

\section{ABSTRACT}

Entrepreneurship is not an inborn skill; it is a product of environment. It involves a complex of economic and social behaviour. To be successful, an entrepreneur has to remain dynamic and responsible to the whole environment. Entrepreneurship can hardly survive under any given circumstances. It can flourish only under right environment. The social factors, culture, government policies, political system, technology, economic conditions, laws, etc influence the growth of entrepreneurship. In fact, the entrepreneurship cannot be kept aloof from the changing social values, ideologies, new emerging aspirations, environmental pressures, religious beliefs, consumer wants, and society needs. Business is a system made up of certain environmental factors which require the entrepreneurs to adopt a dynamic attitude and a new strategy of their own. The paper is tackling the issue of social factors such as Gender, age, caste, Location of the units, Income, educational level, influencing the development of entrepreneurship in Theni District.

Keywords : Entrepreneurship, social factors, culture, government policies, political system, technology, economic conditions, laws, growth of entrepreneurship.

\section{INTRODUCTION}

The entrepreneurial activity at any time is dependent upon a complex and varying combination of socio economic, psychological and other factors. The various environmental factors exercise a strong influence on the personality or personal background of the entrepreneurs. Therefore, any attempt to understand the entrepreneurial spirit among people should include an examination of the socio-economic origins of the entrepreneurs. The process of interaction and an adaption between the individual and his environment goes on continuously. In a developing country like India, a favourable socioeconomic environment could help in exploiting the latent entrepreneurial talents. However, the unfavourable conditions often hinder the emergence of such entrepreneurial talents. Despite these 
situational constraints, today more and more people are entering the field of entrepreneurship in India. The entrepreneurial behaviour and enterprise management among the people are supported and sustained by the growth of enterprise involvement by the social and environmental factors among the respondents. Such information is expected to provide a mechanism to identify the people who have the potential and to plan appropriate training programmes to develop their potential further.

\subsection{OBJECTIVE OF THE STUDY}

The study was undertaken with the following objective

1) To analyse the social factors influencing entrepreneurship in Theni District.

2) To study the factors affecting entrepreneurship.

\subsection{METHODOLOGY}

Research methodology is an important aspect of any research work. It helps the researcher to organize and streamlines the work. To accomplish the objectives of study the researcher had to depend on following.

\section{Primary Data}

Primary data are those which are being collected originally by the researcher for the purpose of our study. Primary data used for this study were collected by distributing the structured questionnaire to the selected Entrepreneurs and personal interviews.

\section{Secondary data}

Secondary data were collected from various Entrepreneurship books, journal, trade magazines, daily newspapers, Entrepreneurs related varies textbooks, government records, websites.

\subsection{SAMPLING DESIGN}

Convenience sampling method has been used. Because the selection of respondents from the population has been selected based on easily available and accessibility.

\subsection{SAMPLE SIZE:}

The primary data for the study had been collected from 100 respondents belonging to different level.

\subsection{TOOLS FOR ANALYIS:}

After collecting the primary data, the field collected information for edited properly. A master table was prepared to consolidate information contained in the collection of data. The data have been analysed by using Simple Percentage with table, Weighted Average, Chi - square test. Friedman test

\section{(a) Percentage Analysis}

Percentage analysis is a simple tool used by all. It is used to given the clear-cut information about the analysis.

\section{Percentage $=$ Individual of respondents $/$ Total number of respondents $\mathrm{X} 100$}

\section{(b) Weighted average method}

Weighted Average Method is used to rank the sources of information. Five-point rating scale is used and each scale has been given a score according to the importance starting from 5 to 1 .

Weighted Average $=\mathrm{X}^{\mathrm{w}}=\mathrm{X}^{\mathrm{w}}=\sum \mathrm{WX}$

Where $\mathrm{X}^{\mathrm{w}}=$ Weighted Arithmetic mean $\mathrm{W}=$ The weightage attached to variables $\mathrm{X}=$ The Variable Value

\section{(c) Chi-Square test}

Chi-square test is a non- parametric test used for comparing a sample Variance to a theoretical population variance. When the cell frequency is more the five the Chi-square test is applied.

$$
x^{2}=\sum(\mathrm{O}-\mathrm{E})^{2} / \mathrm{E}
$$


$\mathrm{O}=$ Observed Frequency

$\mathrm{E}=$ Expected Frequency

$\mathrm{E}=$ Row total X Column total

Grand Total

$\boldsymbol{\mu}=(\mathrm{c}-1)(\mathrm{r}-1)$

$\mu=$ Degrees of freedom

When the calculated value is less than the table value the null hypothesis is accepted.

\subsection{PERIOD OF STUDY:}

The primary data were collected in the academic period in 2019-2020.

\section{METHODS AND MATERIAL}

In a developing country like India, a favourable socio-economic environment could help in exploiting the latent entrepreneurial talents. However, the unfavourable conditions often hinder the emergence of such entrepreneurial talents. Despite these situational constraints, today more and more people are entering the field of entrepreneurship in India. The entrepreneurial behaviour and enterprise management among the people are supported and sustained by the growth of enterprise involvement by the demographic and environmental factors among the respondents. Such information is expected to provide a mechanism to identify the people who have the potential and to plan appropriate training programmes to develop their potential further. Hence, the present part of the study focuses on revealing the profile of the respondents. This chapter deals with the analysis of the social status of the selected entrepreneurs and the problems faced by them.

\subsection{SOCIAL ECONOMIC CONDITIONS}

Social status of the entrepreneurs depends upon their personal character and environment in which they live. The independent social variables such as Gender, age, caste, location of the unit, Income, educational level, were chosen for analysis. Data were collected from the respondents with respect to these factors and the information is presented in the following paragraphs.

\subsection{SIMPLE PERCENTAGE}

\begin{tabular}{|c|c|c|c|}
\hline Demographics & Variables & Frequency & Percentage \\
\hline \multirow{3}{*}{ Gender } & Male & 46 & 46 \\
\cline { 2 - 4 } & Female & 54 & 54 \\
\cline { 2 - 4 } Age & Up to 35 & 29 & 29 \\
\cline { 2 - 4 } & $35-60$ & 28 & 43 \\
\hline \multirow{3}{*}{ Caste } & 60 and Above & 30 & 28 \\
\cline { 2 - 4 } & Forward & 27 & 30 \\
\cline { 2 - 4 } & Backward & 65 & 43 \\
\hline Location of the Unit & SC / ST & 35 & 27 \\
\cline { 2 - 4 } & Rural area & 26 & 35 \\
\hline & Urban area & 26 \\
\hline
\end{tabular}


Dr. S. Iruthaya Kalai Selvam et al Int. J. Sci. Res. Comput. Sci. Eng. Inf. Technol, July-August-2021, 7 (4) : 314-322

\begin{tabular}{|c|c|c|c|}
\hline \multirow{3}{*}{ Income } & $10,000-50,000$ & 21 & 21 \\
\cline { 2 - 4 } & $50,000-1,00,000$ & 34 & 34 \\
\cline { 2 - 4 } & $1,00,000$ \& above & 19 & 19 \\
\hline \multirow{4}{*}{ Educational Level } & Higher with D.TED & 12 & 12 \\
\cline { 2 - 4 } & Graduate with B. ED & 12 & 12 \\
\cline { 2 - 4 } & Post graduate B. ED & 20 & 20 \\
\cline { 2 - 4 } & M.PHIL with B. ED & 56 & 56 \\
\hline
\end{tabular}

1) The results show that about 46 per cent of the respondents are male 54 per cent are female

2) Majority of 43 per cent of the entrepreneurs are less than 60 years and more than 35 years of age and those who are up to 35 years amounted to 29 per cent. The age 60 and above years are having 28 per cent of entrepreneurs belong to above 60 .

3) The study reveals that the majority of the entrepreneurs, that is $43 \%$, were in backward category, $30 \%$ of them were in forward category, only remaining $27 \%$ of the entrepreneurs belonged to SC / ST category.

4) It is found that majority of the entrepreneurs that is 65 per cent were from rural area and 35 percent of them were from urban area.

5) Majority of 34 percent entrepreneurs were in the "50000" - 100000" category followed by 26 percent entrepreneurs in the annual income "up to 10000" 21 percent were in the " 10000 - 50000" category followed by 19 percent were in the 100000 \& above annual income category.

6) 12 percent of the entrepreneurs were higher secondary with D.TED, 12 percentages of the entrepreneurs were Graduate with B. ED, 20 percentages of the entrepreneurs were post graduate with $\mathrm{B}$. ED, and 56 percentages of the entrepreneurs were M. PHIL with B.ED.

The researchers have framed the null hypotheses to understand the association between Entrepreneurship and demographic profile of the respondents.

HO: There is no significant relationship between gender and the level satisfaction of entrepreneurs.

HO: There is no significant relationship between Age and the level of satisfaction of entrepreneurs.

HO: There is no significant relationship between caste and the level of satisfaction of entrepreneurs.

HO: There is no significant relationship between Location of the units and the level of satisfaction of entrepreneurs.

HO: There is no significant relationship between income and the level of satisfaction of entrepreneurs.

HO: There is no significant relationship between educational level and the level of satisfaction of entrepreneurs.

TABLE - 1 Distribution of Respondents by Form of Business Ownership

\begin{tabular}{|c|c|c|c|c|c|c|c|}
\hline S. No & Parameters & $\begin{array}{c}\text { Highly } \\
\text { aware (4) }\end{array}$ & $\begin{array}{c}\text { Aware } \\
(\mathbf{3})\end{array}$ & $\begin{array}{c}\text { Not aware } \\
\mathbf{( 2 )}\end{array}$ & $\begin{array}{c}\text { Utilization } \\
(\mathbf{1})\end{array}$ & $\begin{array}{c}\text { Weighted } \\
\text { Averages }\end{array}$ & Rank \\
\cline { 1 - 7 } 1 & $\begin{array}{c}\text { Sole } \\
\text { proprietorship }\end{array}$ & 11 & 44 & 26 & 19 & \multirow{2}{*}{24.7} & III \\
\cline { 3 - 6 } & & 44 & 132 & 52 & 19 & 24.7 \\
\hline
\end{tabular}


Dr. S. Iruthaya Kalai Selvam et al Int. J. Sci. Res. Comput. Sci. Eng. Inf. Technol, July-August-2021, 7 (4) : 314-322

\begin{tabular}{|c|c|c|c|c|c|c|c|}
\hline \multirow[t]{2}{*}{2} & \multirow[t]{2}{*}{ Partnership } & 44 & 37 & 15 & 04 & \multirow[b]{2}{*}{32.1} & \multirow[b]{2}{*}{$\mathrm{I}$} \\
\hline & & 176 & 111 & 30 & 04 & & \\
\hline \multirow[t]{2}{*}{3} & \multirow[t]{2}{*}{ Company } & 15 & 26 & 18 & 41 & \multirow[b]{2}{*}{21.5} & \multirow[b]{2}{*}{$\mathrm{V}$} \\
\hline & & 60 & 78 & 36 & 41 & & \\
\hline \multirow[t]{2}{*}{4} & \multirow{2}{*}{$\begin{array}{c}\text { Cooperative } \\
\text { Society }\end{array}$} & 19 & 28 & 16 & 37 & \multirow{2}{*}{22.9} & \multirow{2}{*}{ IV } \\
\hline & & 76 & 84 & 32 & 37 & & \\
\hline \multirow[t]{2}{*}{5} & \multirow[t]{2}{*}{ State Enterprise } & 30 & 20 & 35 & 15 & \multirow[b]{2}{*}{26.5} & \multirow[b]{2}{*}{ II } \\
\hline & & 120 & 60 & 70 & 15 & & \\
\hline
\end{tabular}

Source: primary Data

Table1, shows that Partnership has been ranked as first by the entrepreneurs among the five form of business ownership. It is also been found that State Enterprise has ranked as second. Sole proprietorship and Cooperative Society have been ranked as third and fourth respectively. Company was the fifth rank.

TABLE - 2 Factors Affecting Entrepreneurship

\begin{tabular}{|c|c|c|c|c|c|c|c|c|}
\hline S. No & Parameters & $\begin{array}{l}\text { Highly } \\
\text { satisfied } \\
\text { (5) }\end{array}$ & $\begin{array}{l}\text { Satisfied } \\
\quad(4)\end{array}$ & $\begin{array}{c}\text { Average } \\
\text { (3) }\end{array}$ & $\begin{array}{l}\text { Dissatisfied } \\
\text { (2) }\end{array}$ & $\begin{array}{c}\text { Highly } \\
\text { Dissatisfied } \\
(1)\end{array}$ & $\begin{array}{l}\text { Weighted } \\
\text { Averages }\end{array}$ & Rank \\
\hline \multirow[t]{2}{*}{1} & \multirow{2}{*}{$\begin{array}{l}\text { Aspiration and } \\
\text { Attitude }\end{array}$} & 33 & 28 & 18 & 12 & 09 & \multirow[b]{2}{*}{36.4} & \multirow[t]{2}{*}{ III } \\
\hline & & 165 & 112 & 54 & 24 & 09 & & \\
\hline \multirow[t]{2}{*}{2} & \multirow[t]{2}{*}{ Personal Factors } & 30 & 25 & 15 & 18 & 12 & \multirow[b]{2}{*}{34.3} & \multirow[t]{2}{*}{ VI } \\
\hline & & 150 & 100 & 45 & 36 & 12 & & \\
\hline \multirow[t]{2}{*}{3} & \multirow{2}{*}{$\begin{array}{c}\text { Family } \\
\text { Circumstances }\end{array}$} & 45 & 38 & 10 & 04 & 03 & \multirow[t]{2}{*}{41.8} & \multirow[t]{2}{*}{$\mathrm{I}$} \\
\hline & & 225 & 152 & 30 & 08 & 03 & & \\
\hline \multirow[t]{2}{*}{4} & \multirow{2}{*}{$\begin{array}{l}\text { Government } \\
\text { policies, } \\
\text { Facilities, and } \\
\text { Incentives }\end{array}$} & 31 & 20 & 16 & 18 & 15 & \multirow[t]{2}{*}{33.4} & \multirow[t]{2}{*}{ VIII } \\
\hline & & 155 & 80 & 48 & 36 & 15 & & \\
\hline \multirow[t]{2}{*}{5} & \multirow{2}{*}{$\begin{array}{c}\text { Social and } \\
\text { Cultural Factors }\end{array}$} & 28 & 26 & 19 & 17 & 10 & \multirow[t]{2}{*}{34.5} & \multirow[t]{2}{*}{$\mathrm{V}$} \\
\hline & & 140 & 104 & 57 & 34 & 10 & & \\
\hline \multirow[t]{2}{*}{6} & \multirow{2}{*}{$\begin{array}{l}\text { Progeny and } \\
\text { Traditions }\end{array}$} & 19 & 38 & 17 & 18 & 08 & \multirow[t]{2}{*}{34.2} & \multirow[t]{2}{*}{ VII } \\
\hline & & 95 & 152 & 51 & 36 & 08 & & \\
\hline \multirow[t]{2}{*}{7} & \multirow{2}{*}{$\begin{array}{c}\text { Business } \\
\text { Competition }\end{array}$} & 44 & 35 & 13 & 03 & 05 & \multirow[t]{2}{*}{41} & \multirow[t]{2}{*}{ II } \\
\hline & & 220 & 140 & 39 & 06 & 05 & & \\
\hline \multirow[t]{2}{*}{8} & \multirow{2}{*}{$\begin{array}{l}\text { Economic and } \\
\text { Business } \\
\text { Environment }\end{array}$} & 26 & 19 & 14 & 21 & 20 & \multirow[t]{2}{*}{31} & \multirow[t]{2}{*}{ IX } \\
\hline & & 130 & 76 & 42 & 42 & 20 & & \\
\hline \multirow[t]{2}{*}{9} & \multirow[t]{2}{*}{ Support System } & 16 & 19 & 14 & 29 & 22 & \multirow[t]{2}{*}{27.8} & $\mathrm{X}$ \\
\hline & & 80 & 76 & 42 & 58 & 22 & & \\
\hline
\end{tabular}


Dr. S. Iruthaya Kalai Selvam et al Int. J. Sci. Res. Comput. Sci. Eng. Inf. Technol, July-August-2021, 7 (4) : 314-322

\begin{tabular}{|c|c|c|c|c|c|c|c|c|}
\hline \multirow[t]{2}{*}{10} & \multirow{2}{*}{$\begin{array}{l}\text { Attitude of Big } \\
\text { Entrepreneurs }\end{array}$} & 26 & 31 & 16 & 17 & 10 & \multirow[t]{2}{*}{34.6} & \multirow[t]{2}{*}{ IV } \\
\hline & & 130 & 124 & 48 & 34 & 10 & & \\
\hline \multirow[t]{3}{*}{11} & \multirow{3}{*}{$\begin{array}{c}\text { Entrepreneurship } \\
\text { Oriented } \\
\text { Education and } \\
\text { Training }\end{array}$} & 13 & 16 & 19 & 21 & 31 & \multirow[t]{3}{*}{25.9} & \multirow[t]{3}{*}{ XI } \\
\hline & & & & & & & & \\
\hline & & 65 & 64 & 57 & 42 & 31 & & \\
\hline \multirow[t]{2}{*}{12} & \multirow{2}{*}{$\begin{array}{c}\text { Role of Banks } \\
\text { and Financial } \\
\text { Institutions }\end{array}$} & 10 & 12 & 15 & 26 & 37 & \multirow[t]{2}{*}{23.2} & \multirow[t]{2}{*}{ XII } \\
\hline & & 50 & 48 & 45 & 52 & 37 & & \\
\hline
\end{tabular}

Source: Primary Data

Table 2, shows that Family Circumstances has been ranked as first by the entrepreneurs among the towel factors affecting entrepreneurship. It is also been found that Business Competition and Aspiration and Attitude have been ranked as second and third respectively. Attitude of Big Entrepreneurs and Social and Cultural Factors have been ranked as fourth and fifth respectively. Personal Factors and Progeny and Traditions have been ranked as sixth and seventh respectively. Government policies, Facilities, and Incentives and Economic and Business Environment have been ranked as eighth and ninth respectively. Support System and Entrepreneurship Oriented Education and Training have been ranked as tenth and eleventh respectively. Role of Banks and Financial Institutions was the twelveth rank.

\section{III.CHI-SQUARE TEST}

\section{A) Gender of the Respondents}

$$
\chi^{2}=\sum \mathrm{O}-\mathrm{E}^{2} / \mathrm{E}=4.682629
$$

$$
\text { Degree of freedom } \mathrm{V}=(\mathrm{r}-1)(\mathrm{c}-1)
$$

$$
\begin{aligned}
= & (2-1)(3-1)=2 \\
& \chi^{2} 0.05=5.99
\end{aligned}
$$

Since the calculated value of $\chi^{2}$ is less than the table value the hypothesis has been accepted. Therefore, it is concluded that there is significant relationship between Gender and the level of respondents.

\begin{tabular}{|c|l|l|l|l|}
\hline O & $\mathrm{E}$ & $\mathrm{O}-\mathrm{E}$ & $(\mathrm{O}-\mathrm{E})^{2}$ & $(\mathrm{O}-\mathrm{E})^{2} / \mathrm{E}$ \\
\hline 14 & 10.12 & 3.88 & 15.0544 & 1.487589 \\
\hline 8 & 11.88 & -3.88 & 15.0544 & 1.267205 \\
\hline 20 & 24.84 & -4.84 & 23.4256 & 0.94306 \\
\hline 34 & 29.16 & 4.84 & 23.4256 & 0.803347 \\
\hline 10 & 11.04 & -1.04 & 1.0816 & 0.097971 \\
\hline 14 & 12.96 & 1.04 & 1.0816 & 0.083457 \\
\cline { 4 - 5 } & & & $\chi^{2}$ & 4.682629 \\
\cline { 4 - 5 } & \multicolumn{2}{|r}{} & &
\end{tabular}

B) Age wise classification the Respondents

$$
\chi^{2}=\sum(\mathrm{O}-\mathrm{E}) 2 / \mathrm{E}=0.621102
$$

Degree of freedom $\mathrm{v}=(\mathrm{r}-1)(\mathrm{c}-1)$

$$
\begin{aligned}
= & (3-1)(3-1)=4 \\
& \chi^{2} 0.05=9.49
\end{aligned}
$$

Since the calculated value of $\chi^{2}$ is less than the table value the hypothesis has been accepted. Therefore, it is concluded that there is significant relationship between age and the level of respondents. 
Dr. S. Iruthaya Kalai Selvam et al Int. J. Sci. Res. Comput. Sci. Eng. Inf. Technol, July-August-2021, 7 (4) : 314-322

\begin{tabular}{|c|c|c|c|c|}
\hline \multicolumn{1}{|l|}{$\mathrm{O}$} & $\mathrm{E}$ & $\mathrm{O}-\mathrm{E}$ & $(\mathrm{O}-\mathrm{E}) 2$ & $(\mathrm{O}-\mathrm{E}) 2 / \mathrm{E}$ \\
\hline 7 & 6.38 & 0.62 & 0.3844 & 0.060251 \\
\hline 16 & 15.66 & 0.34 & 0.1156 & 0.007382 \\
\hline 6 & 6.96 & -0.96 & 0.9216 & 0.132414 \\
\hline 10 & 9.46 & 0.54 & 0.2916 & 0.030825 \\
\hline 22 & 23.22 & -1.22 & 1.4884 & 0.0641 \\
\hline 11 & 10.32 & 0.68 & 0.4624 & 0.044806 \\
\hline 5 & 6.16 & -1.16 & 1.3456 & 0.218442 \\
\hline 16 & 15.12 & 0.88 & 0.7744 & 0.051217 \\
\hline 7 & 6.72 & 0.28 & 0.0784 & 0.011667 \\
\hline & & & $x 2$ & 0.621102 \\
\cline { 4 - 5 } & & &
\end{tabular}

$$
\begin{gathered}
=(2-1)(3-1)=2 \\
\chi^{2} 0.05=5.99
\end{gathered}
$$

Since the calculated value of $\chi^{2}$ is less than the table value the hypothesis has been accepted. Therefore, it is concluded that there is significant relationship between Location of the units and the level of respondents.

\begin{tabular}{|l|l|c|c|c|}
\hline O & E & O-E & $(\mathrm{O}-\mathrm{E})^{2}$ & $(\mathrm{O}-\mathrm{E})^{2} / \mathrm{E}$ \\
\hline 14 & 14.3 & -0.3 & 0.09 & 0.006294 \\
\hline 36 & 35.1 & 0.9 & 0.81 & 0.023077 \\
\hline 15 & 15.6 & -0.6 & 0.36 & 0.023077 \\
\hline 8 & 7.7 & 0.3 & 0.09 & 0.011688 \\
\hline 18 & 18.9 & -0.9 & 0.81 & 0.042857 \\
\hline 9 & 8.4 & 0.6 & 0.36 & 0.042857 \\
\cline { 4 - 5 } & & & $\chi^{2}$ & 0.14985 \\
\cline { 4 - 5 } & & & &
\end{tabular}

Since the calculated value of $\chi^{2}$ is less than the table value the hypothesis has been accepted. Therefore, it is concluded that there is significant relationship between caste and the level of respondents.

\begin{tabular}{|c|c|c|c|c|}
\hline \multicolumn{1}{|l|}{$\mathbf{O}$} & $\mathbf{E}$ & \multicolumn{1}{l|}{ O-E } & $(\mathbf{O - E}) 2$ & $(\mathbf{O - E}) \mathbf{2} / \mathbf{E}$ \\
\hline 8 & 6.6 & 1.4 & 1.96 & 0.29697 \\
\hline 14 & 16.2 & -2.2 & 4.84 & 0.298765 \\
\hline 8 & 7.2 & 0.8 & 0.64 & 0.088889 \\
\hline 8 & 9.46 & -1.46 & 2.1316 & 0.225328 \\
\hline 24 & 23.22 & 0.78 & 0.6084 & 0.026202 \\
\hline 11 & 10.32 & 0.68 & 0.4624 & 0.044806 \\
\hline 6 & 5.94 & 0.06 & 0.0036 & 0.000606 \\
\hline 16 & 14.58 & 1.42 & 2.0164 & 0.138299 \\
\hline 5 & 6.48 & -1.48 & 2.1904 & 0.338025 \\
\cline { 4 - 5 } & & & $\chi^{2}$ & $\mathbf{1 . 4 5 7 8 8 9}$ \\
\cline { 4 - 5 } & & &
\end{tabular}

E) Income of the Respondents:

$$
\mathrm{X}^{2}=(\mathrm{O}-\mathrm{E})^{2} / \mathrm{E}=7.887692
$$

Degree of freedom $\mathrm{V}=(\mathrm{r}-1)(\mathrm{c}-1)$

$$
=(4-1)(3-1)=6
$$

Table value at $\chi^{2}$ confined level $=12.6$

Since the calculated value of $\chi^{2}$ is less than the table value the hypothesis has been accepted. Therefore, it is concluded that there is significant relationship between Income and the level of respondents.

\section{D) Location of the Unit}

$$
\chi^{2}=\sum \mathrm{O}-\mathrm{E}^{2} / \mathrm{E}=0.14985
$$

Degree of freedom $V=(r-1)(c-1)$ 
Dr. S. Iruthaya Kalai Selvam et al Int. J. Sci. Res. Comput. Sci. Eng. Inf. Technol, July-August-2021, 7 (4) : 314-322

\begin{tabular}{|c|c|c|c|c|}
\hline $\mathrm{O}$ & $E$ & O-E & (O-E)2 & $(\mathrm{O}-\mathrm{E}) 2 / \mathrm{E}$ \\
\hline 6 & 5.72 & 0.28 & 0.0784 & 0.013706 \\
\hline 14 & 14.04 & -0.04 & 0.0016 & 0.000114 \\
\hline 6 & 6.24 & -0.24 & 0.0576 & 0.009231 \\
\hline 5 & 4.62 & 0.38 & 0.1444 & 0.031255 \\
\hline 8 & 11.34 & -3.34 & 11.1556 & 0.983739 \\
\hline 8 & 5.04 & 2.96 & 8.7616 & 0.738413 \\
\hline 5 & 7.48 & -2.48 & 6.1504 & 1.822246 \\
\hline 24 & 18.36 & 5.64 & 31.8096 & 1.732549 \\
\hline 5 & 8.16 & -3.16 & 9.9856 & 1.223725 \\
\hline 6 & 4.18 & 1.82 & 3.3124 & 0.79244 \\
\hline 8 & 10.26 & -2.26 & 5.1076 & 0.497817 \\
\hline 5 & 4.56 & 0.44 & 0.1936 & 0.042456 \\
\hline & & & $\chi^{2}$ & 7.887692 \\
\hline
\end{tabular}

\begin{tabular}{|c|c|c|c|c|}
\hline $\mathrm{O}$ & $\mathrm{E}$ & $\mathrm{O}-\mathrm{E}$ & $(\mathrm{O}-\mathrm{E}) 2$ & $(\mathrm{O}-\mathrm{E}) 2 / \mathrm{E}$ \\
\hline 4 & 4.9 & -0.9 & 0.81 & 0.165 \\
\hline 2 & 5.6 & -3.6 & 12.96 & 2.314 \\
\hline 9 & 8.05 & 0.95 & 0.90 & 0.112 \\
\hline 18 & 14 & 4 & 16 & 1.143 \\
\hline 2 & 2.24 & -0.45 & 0.20 & 0.083 \\
\hline 6 & 6.72 & -0.72 & 0.52 & 0.08 \\
\hline 10 & 5.6 & 4.4 & 19.36 & 3.46 \\
\hline 10 & 11.04 & -1.04 & 1.08 & 0.010 \\
\hline 18 & 19.2 & -1.2 & 1.44 & 0.08 \\
\hline 4 & 3.36 & 0.64 & 0.41 & 0.122 \\
\hline 4 & 2.38 & 1.62 & 2.62 & 1.10 \\
\hline 4 & 2.72 & 1.28 & 1.64 & 0.60 \\
\hline 2 & 3.91 & 0.09 & 8.1 & 2.07 \\
\hline 9 & 6.8 & -2.8 & 7.84 & 1.15 \\
\hline 18 & 1.19 & -0.19 & 0.0361 & 0.030 \\
\hline & & & $\chi^{2}$ & 11.51 \\
\cline { 4 - 5 } & & & & \\
& & &
\end{tabular}

\section{IV.FINDINGS}

Most of the entrepreneurs entered enterprises at the age of $35-60$ years.

Nearly $54 \%$ of the entrepreneurs were female

Three fourth of the entrepreneurs were either $\mathrm{M}$. PHIL with B. ED or Post graduate

B. ED Qualified.

$$
\mathrm{X}^{2}=(\mathrm{O}-\mathrm{E})^{2} / \mathrm{E}=11.51
$$

Degree of freedom $\mathrm{V}=(\mathrm{r}-1)(\mathrm{c}-1)$

$$
=(5-1)(3-1)=8
$$

Table value at $\chi^{2}$ confined level $=12.6$

Since the calculated value of $\chi^{2}$ is less than the table value the hypothesis has been accepted. Therefore, it is concluded that there is significant relationship between Education and the level of respondents.

About $43 \%$ entrepreneurs belonged to backward caste.

More than $65 \%$ of the entrepreneurs were from rural area.

\section{CONCLUSION}

From the foregoing discussion it is vivid that entrepreneurship is not influenced by a single factor but is the outcome of the interaction and combination of various social factors. Encouraging governmental policy and social recognition influence a person to become an entrepreneur. Our educational 
system should be modified so as to produce more job creators rather than job seekers.

\section{REFERENCES}

[1]. Gupta, S.P. Statistical Methods, Sultan Chand \& Sons, New Delhi, Twenty - Fifth Edition, 1990.

[2]. Manoharan, M. Statistical Methods, Palani Paramount Publications, Palani, 2004.

[3]. Kothari C, R (2007) Research Methodology, Methods and Techniques, New Deli, New Age International (p) Ltd.

[4]. Gupta, C.B., Srinivasan, N.P., Entrepreneurial Development, Sultan Chand \& Sons, New Delhi, 2004.

[5]. Manickavasagam, V. and Vethirajan, C., "Contribution of Small-Scale Industry to the Indian Economy”, Facts for You, May 2002.

[6]. Ravindra Gowda, K. and Shivakanth Shetty, A., "SMEs" Contribution to Inclusive Growth and Employment Opportunities in India", Southern Economist, Vol. 48, 23, April 1, 2010.

[7]. Vasant Desai, Dynamics of Entrepreneurial Development and Management, Himalaya Publishing House, Mumbai, 2001.

[8]. Saravanavel, P., Entrepreneurial Development Principles Polices and Programmes, Ess Pee kay Publishing House, Madras, 1997.

\section{BOOKS}

[9]. Bhagwan Prasad. 2003. Developing Entrepreneurial Skills among Management and Engineering Graduates, Osmania University, Hyderabad (AICTE-sponsored project).

[10].Saini, J.S. and B.S. Rathore. 2001. Entrepreneurship - Theory and Practice, Wheeler Publishing, New Delhi.

[11].Rathore, B.S. and S.K. Dhameja (eds.). 1999. Entrepreneurship in the 21st Century, Rawat Publications, Jaipur.
[12].Saini, J.S. 1996. Entrepreneurship Development: Programmes and Practices, Deep and Deep Publications, New Delhi.

[13].Gupta, C.B and Dr. Srinivasan, N.P., Entreprenurship Development in India, sultha Chand \& son.

\section{Cite this article as :}

Dr. S. Iruthaya Kalai Selvam, Asha Banu, "Social Factors Influencing Entrepreneurship A Study On With Special Reference To Theni District", International Journal of Scientific Research in Computer Science, Engineering and Information Technology (IJSRCSEIT), ISSN : 2456-3307, Volume 7 Issue 4, pp. 314-322, July-August 2021. Available at doi : https://doi.org/10.32628/CSEIT217485 Journal URL : https://ijsrcseit.com/CSEIT217485 